\title{
Economic burden of the management of metastatic castrate-resistant prostate cancer in Italy: a cost of illness study [Corrigendum]
}

\author{
Restelli U, Ceresoli GL, Croce D et al. Economic burden \\ of the management of metastatic castrate-resistant prostate \\ cancer in Italy: a cost of illness study. Cancer Management \\ and Research. 2017;9:789-800.
}

On page 796, above the Disclosure section, the Acknowledgment section is missing. The missing text is:

\section{Acknowledgment}

The authors thank Ray Hill, an independent medical writer, who provided English-language editing and journal styling prior to submission on behalf of Health Publishing \& Services Srl. Editorial support was funded through an unconditional contribution by Bayer SpA.

\section{Publish your work in this journal}

Cancer Management and Research is an international, peer-reviewed open access journal focusing on cancer research and the optimal use of preventative and integrated treatment interventions to achieve improved outcomes, enhanced survival and quality of life for the cancer patient. The manuscript management system is completely online and includes a very quick and fair peer-review system, which is all easy to use. Visit http://www.dovepress.com/testimonials.php to read real quotes from published authors. 